\title{
The Need to Balance the Blend: Online versus Face-to-Face Teaching in an Introductory Accounting Subject
}

\author{
Lily Wong and Arthur Tatnall \\ Victoria University, Melbourne, Victoria, Australia
}

lily.wong@vu.edu.au arthur.tatnall@vu.edu.au

\begin{abstract}
To remain globally competitive, there is increasing pressure for universities to incorporate a greater use of technology and innovation into their curriculum. In response, many higher education institutions have adopted a blended learning approach, which combines traditional face-toface delivery with online teaching resources, to deliver course content. This paper documents the implementation of online resources in a first-year accounting unit, outlines subsequent changes and monitors its impact on learning outcomes. Whilst in its early stages, this preliminary work on action research will form the basis of determining an optimal blend of traditional and online learning environments for introductory accounting students. This research will endeavour to improve the structure of the curriculum and to positively impact on student learning outcomes.
\end{abstract}

Keywords: action research, blended learning, innovation, introductory accounting, learning outcomes.

\section{Introduction}

Rapid developments in information and communication technologies have made a significant impact on the content and delivery of course curriculum in higher education (Nicol, 2006).

One of Victoria University's key strategies is to enhance the quality of the learning experience by incorporating a greater use of technology in the teaching and learning process; this trend toward blended learning is emerging as perhaps the most prominent method of delivery in higher education (Bonk \& Graham, 2006).

It has been suggested that the use of technology in educational settings assists in the achievement of learning outcomes (Wells, Fieger, \& de Lange, 2008). The aim of this research project is to document the integration of online resources into an introductory accounting unit. A review of key performance measures before and after these technological enhancements will be used to determine its impact on learning outcomes.

Material published as part of this publication, either on-line or in print, is copy righted by the Informing Science Institute. Permission to make digital or paper copy of part or all of these works for personal or classroom use is granted without fee provided that the copies are not made or distributed for profit or commercial advantage AND that copies 1) bear this notice in full and 2) give the full citation on the first page. It is permissible to abstract these works so long as cred it is given. To copy in all other cases or to republish or to post on a server or to redistribute to lists requires specific permission and payment of a fee. Contact Publisher@InformingScience.org to request redistribution permission.

The project objective and university strategy was to be achieved with the introduction of WebCT, an online learning platform provided by the Blackboard Learning System, which cons ists of a combination of internet technologies. It has the potential to provide lectures and other content to students online in a variety of forms including, video, audio, text, images and animations. Its com- 
munication tools also provide a range of methods for students to communicate with each other and their lecturers across the internet. Various assessment tasks can also be undertaken online and statistical details are available to track student performance. Because Blackboard uses the internet through a password protected login, students can access the learning environment from anywhere with internet access, at any time. This flexible and secure access to a unit enables learning across geographical boundaries and time zones.

Victoria University's largest accounting unit, BAO1101 Accounting for Decision Making, is a first-year core unit for all students enrolled in the Bachelor of Business course. Negative attitudes towards accounting are not rare among introductory accounting students (Mladenovic, 2000) and earlier studies suggest that changes in accounting education should begin with the very first subject in accounting as it not only sets the tone, but also provides the foundation for further interest in accounting studies (Mintz \& Cherry, 1993).

The students enrolled in this first-year core accounting unit are a very diverse group comprising accounting and non-accounting students from a broad spectrum of business degrees which range from music through to marketing. These students have vastly different prior experiences in studying accounting and the ir expectations about the unit are also varied. It is important that the curriculum material used in the unit is developed with an understanding of the differences among the many students in the cohort and that it meet the varying needs of these students. Whilst the focus of this pre liminary research is on the outcomes of the local students, further research on the overseas cohort is intended.

\section{Methodology}

To determine the impact of a blended learning approach on learning outcomes, a quantitative approach is used for this research. To gather the data required, a number of sources were utilised. This includes information retrieved from the university's student database, the Victoria University Student Information System (VUSIS), statistics on student participation rates for online tests accessible through the analytical tools available on the WebCT course management system and academic performance measures calculated from comprehensive records kept on student assessment. Student evaluations for this unit comprise a set of criteria against which the unit is rated. This covers appropriateness of workload and assessment, quality of teaching materials, ability of the instructor to motivate students and relevance of course content. The final question asks students to provide an overall rating of the quality of the unit on a scale from 1 for 'Very Poor' to 5 for 'Very Good'. These evaluations are compulsory and required to be formally conducted by an external administrator at the end of each semester.

\section{Demographic Profile}

It has been acknowledged that age, sex, socio-economic background and ethnicity contribute to and shape students' expectations of university, their adjustment to being university students, and ultimately their overall teaching and learning experience (McInnes, James, \& Mc Naught, 1995). This determined the demographic factors to be included as possible factors of interest in this study.

Table 1 provides a demographic profile of the students enrolled in this unit over the 4 year period under review. The first column provides the details for the base year 2005, the year prior to the introduction of WebCT. This will be used as a benchmark for comparison from 2006 through to 2008. 
Table 1: Demographic Profile of Students Enrolled In Unit

\begin{tabular}{|c|c|c|c|c|c|}
\hline & \multirow{2}{*}{$\begin{array}{l}\text { Prior to } \\
\text { WebCT } \\
2005 \\
\end{array}$} & \multicolumn{3}{|c|}{$\begin{array}{l}\text { With } \\
\text { WebCT }\end{array}$} & \multirow[b]{2}{*}{ Total } \\
\hline & & 2006 & 2007 & 2008 & \\
\hline Total Number of Students * & 1,082 & 1,335 & 1,385 & 1,278 & 5,080 \\
\hline Gender & $\%$ & $\%$ & $\%$ & $\%$ & $\%$ \\
\hline Female & 49.7 & 51.3 & 50.7 & 48.7 & 50.2 \\
\hline Male & 50.3 & 48.7 & 49.3 & 51.3 & 49.8 \\
\hline Language Spoken at Home & $\%$ & $\%$ & $\%$ & $\%$ & $\%$ \\
\hline Non-English & 41.9 & 39.6 & 40.3 & 38.4 & 40.0 \\
\hline English & 29.3 & 34.1 & 33.7 & 44.9 & 35.7 \\
\hline Unknown & 28.8 & 26.3 & 26.0 & 16.7 & 24.3 \\
\hline Country of B irth & $\%$ & $\%$ & $\%$ & $\%$ & $\%$ \\
\hline Australia & 62.5 & 68.2 & 70.1 & 70.8 & 68.1 \\
\hline Africa & 4.7 & 3.8 & 3.4 & 3.1 & 3.7 \\
\hline Asia & 13.8 & 13.0 & 12.7 & 11.7 & 12.7 \\
\hline Europe & 5.7 & 4.7 & 5.1 & 4.9 & 5.0 \\
\hline New Zealand & 0.6 & 1.0 & 0.7 & 1.2 & 0.9 \\
\hline Middle East & 2.6 & 2.2 & 2.1 & 1.6 & 2.1 \\
\hline United States of America & 1.4 & 1.3 & 1.2 & 0.8 & 1.2 \\
\hline United Kingdom & 1.1 & 1.0 & 1.2 & 0.8 & 1.0 \\
\hline Unknown & 7.9 & 4.7 & 3.3 & 5.1 & 5.1 \\
\hline Mode of Study & $\%$ & $\%$ & $\%$ & $\%$ & $\%$ \\
\hline Full-Time & 86.4 & 87.8 & 86.1 & 88.3 & 87.1 \\
\hline Part-Time & 13.6 & 12.2 & 13.9 & 11.7 & 12.9 \\
\hline Age & $\%$ & $\%$ & $\%$ & $\%$ & $\%$ \\
\hline Less than 20 years & 63.8 & 64.3 & 65.9 & 72.1 & 66.6 \\
\hline $20-29$ years & 30.7 & 31.1 & 30.0 & 25.3 & 29.3 \\
\hline 30 years + & 5.5 & 4.6 & 4.1 & 2.6 & 4.1 \\
\hline Socio-Economic Status & $\%$ & $\%$ & $\%$ & $\%$ & $\%$ \\
\hline High & 22.0 & 20.1 & 20.7 & 20.3 & 20.7 \\
\hline Low & 30.9 & 33.2 & 33.6 & 33.2 & 32.8 \\
\hline Medium & 46.7 & 46.1 & 44.8 & 45.5 & 45.7 \\
\hline Unknown & 0.5 & 0.6 & 0.9 & 1.0 & 0.7 \\
\hline
\end{tabular}

Source: VUSIS Enrolment Data 2005 to 2008

\section{*Explanatory Note}

The demographic details available from VUSIS show data for the total number of students enrolled for the whole academic year which includes Semester 1, 2 and 3 (Summer School).

\section{Gender}

The student population shows an almost equal representation of gender over the 4 year period, however, a slight bias is noted in 2008 with males comprising $51.3 \%$ of the sample, compared to females $48.7 \%$. 


\section{Language Spoken at Home}

These results show a reversal in trends from 2005 to 2008. In 2005, the most prominent language spoken at home was a language other than English accounting for $41.9 \%$ of the sample. By 2008 , this gradually declined to $38.4 \%$. In contrast, the proportion of English speaking students has grown considerably, increasing from $29.3 \%$ to $44.9 \%$ over the same period. It is acknowledged that as a significant portion of this sample remains unknown, these figures need to be interpreted with caution.

\section{Country of Birth}

The student population is predominantly Australian born and an upward trend has continued from $62.5 \%$ to $70.8 \%$ over the four years. This seems to be consistent with the increase in English speaking students over the same period. There is, however, a considerable gap between the next most significant groups, with Asian-born students making up 13.8\%, followed by European-born students accounting for $5.7 \%$ of this group in 2005. A slow decline in these percentages from 2006 onwards is reported for both groups.

\section{Mode of Study}

The vast majority of students were studying in full-time mode, with only $13.6 \%$ studying in parttime mode in 2005. Over the four year period, the proportion of full-time students increased from $86.4 \%$ to $88.3 \%$ whilst the proportion of part-time students decreased from $13.6 \%$ to $11.7 \%$.

\section{Age}

In 2005, the dominant group are those students less than 20 years old representing $63.8 \%$ within this category, $30.7 \%$ are students between $20-29$ years of age, with only $5.5 \%$ of mature students aged 30 years or older. By 2008, the proportion of younger students showed a marked rise to $72.1 \%$, whilst subsequent decreases in the number of students from the latter age groups is reported.

\section{Socio-Economic Status}

The largest proportions of students are those from a medium socio-economic background accounting for $46.7 \%$ of the student population in 2005 . This is followed by $30.9 \%$ of students from a low socio-economic status, with $22 \%$ from a high socio-economic status. The numbers of students from a high and medium socio-economic status have declined slightly over the four year period, whilst a noticeable increase from $30.9 \%$ to $33.2 \%$ by 2008 is recorded for students from a lower socio-economic status.

\section{ENTER Scores}

The Equivalent National Tertiary Entrance Rank, otherwise known as the 'ENTER' score, is an overall ranking system used by Australian universities to select students for their courses. It is measured on a scale from 0 to 99.95 and is calculated from the students' study scores attained in their final year of secondary education. Generally, a higher ENTER score reflects a higher level of academic achievement and is therefore preferential in the selection of students into university courses. 
Table 2: ENTER Scores

\begin{tabular}{|l|c|c|c|c|c|}
\hline & $\mathbf{2 0 0 5}$ & $\mathbf{2 0 0 6}$ & $\mathbf{2 0 0 7}$ & $\mathbf{2 0 0 8}$ & Total \\
\hline Total Number of Students & $\mathbf{1 , 0 8 2}$ & $\mathbf{1 , 3 3 5}$ & $\mathbf{1 , 3 8 5}$ & $\mathbf{1 , 2 7 8}$ & $\mathbf{5 , 0 8 0}$ \\
\hline 49 and under & $17.8 \%$ & $18.4 \%$ & $9.5 \%$ & $5.2 \%$ & $\mathbf{1 2 . 5 \%}$ \\
\hline $50-59$ & $12.9 \%$ & $11.9 \%$ & $5.3 \%$ & $2.7 \%$ & $\mathbf{8 . 0 \%}$ \\
\hline $60-69$ & $15.1 \%$ & $24.0 \%$ & $6.2 \%$ & $3.7 \%$ & $\mathbf{1 2 . 1 \%}$ \\
\hline $70-79$ & $22.5 \%$ & $17.3 \%$ & $4.5 \%$ & $1.9 \%$ & $\mathbf{1 1 . 1 \%}$ \\
\hline 80 and over & $10.8 \%$ & $7.0 \%$ & $2.9 \%$ & $0.8 \%$ & $\mathbf{5 . 1 \%}$ \\
\hline Unknown & $20.8 \%$ & $21.4 \%$ & $71.6 \%$ & $85.7 \%$ & $\mathbf{5 1 . 1 \%}$ \\
\hline
\end{tabular}

Source: VUSIS Enrolment Data 2005 to 2008

Due to the incomplete nature of the data in Table 2 and, in particular, the large portion of 'unknown' scores for 2007 and 2008, it is acknowledged that the usefulness of these details is limited. However, a brief reference to the ENTER scores for 2005 and 2006 may provide some insight into the academic profile of students accepted into this unit.

It may be interpreted that in 2006 there seemed to be an upward shift in the percentage of students accepted with lower ENTER scores. The most noticeable of these is the increase from $15.1 \%$ to $24 \%$ for students with a score of '60 to 69' from 2005 to 2006 respectively. Over the same period, a slight increase in the percentage of students accepted from the lower end of ' 49 and under' is noted. It also appears that students with the higher ENTER scores may have accepted offers from competing universities with this percentage declining from $10.8 \%$ to $7 \%$ between 2005 and 2006.

\section{The Trend Toward Blended Learning}

Garrison and Vaughan (2008, pp. 144-145) identify 3 major changes in higher education; unprecedented advances in communication technology; new challenges within institutions resulting in less contact time with academic staff; and recognition that traditional methods are unable to address the need for higher-order learning experiences and outcomes demanded by a changing know ledge and communication-based society. These changes have led to the emergence of blended learning. According to Bonk and Graham (2006, p.5), blended learning "is part of the

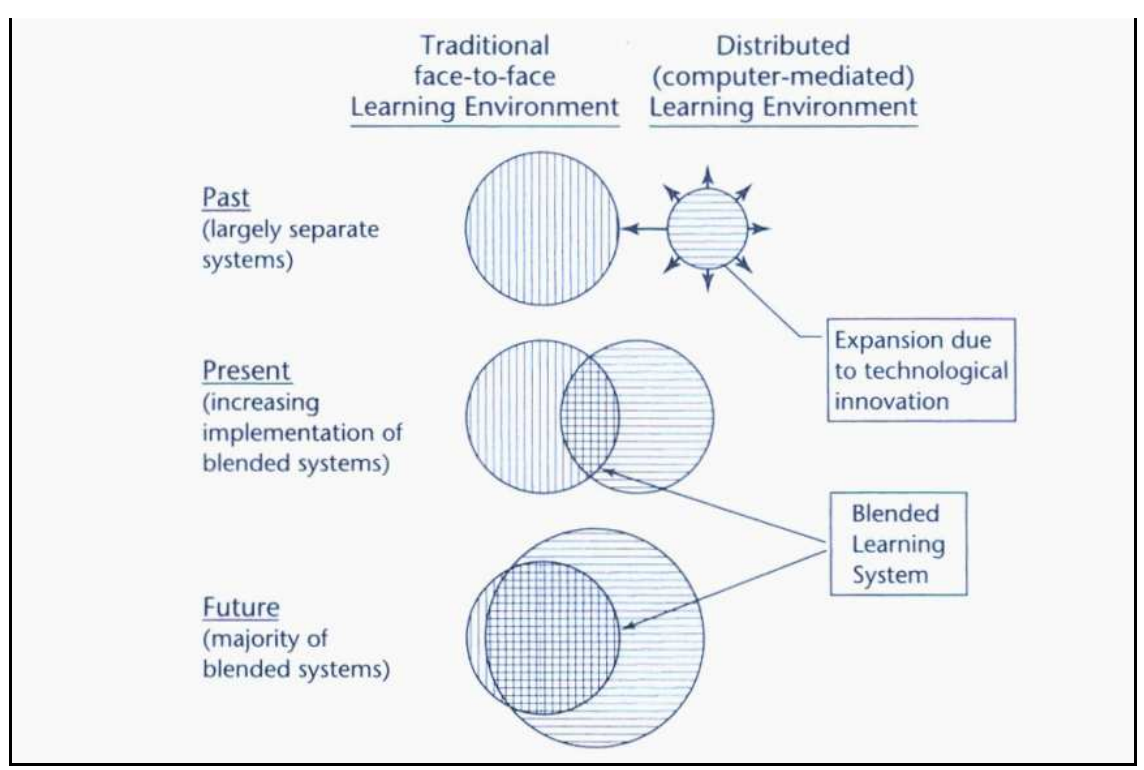

Figure 1 - Conve rgence of Traditional Face-to-Face and Computer Mediated Learning Environments (Bonk \& Graham, 2006, p. 6) 
ongoing convergence of two archetypal learning environments"; the traditional face-to-face and the computer-mediated learning environment, which in the past, had remained separate.

As shown in Figure 1, "the increased level of integration of information communication technologies into the traditional face-to-face learning environment has led to the convergence of these two approaches" (Bonk \& Graham, 2006, p. 6)

"Whist it is acknowledged that it is impossible to predict what the future holds, there is some certainty that the trend toward blended learning systems will increase" (Bonk \& Graham, 2006, p. 7).

\section{Definitional Complexities of Blended Learning}

A review of current literature has provided a diversity of definitions and interpretations of the term 'blended learning'. It is often described as 'the mix of traditional methods of teaching, such as face-to-face teaching and online teaching'. Due to its simplicity, this is perhaps the most common meaning of blended learning used in a higher education context (Bliuc, Goodyear, \& Ellis, 2007). However, a more comprehensive definition is offered by (Garrison \& Vaughan, 2008, p. 5), whereby 'blended learning is the thoughtful fusion of face-to face oral communication and online learning experiences. The basic principle is that face-to face oral communication and online written communication are optimally integrated such that the strengths of each are blended into a unique learning experience congruent with the context and intended educational purpose'. A quantitative approach is adopted by The Sloan Consortium which refers to blended education as a 'course that blends face-to-face and on-line delivery', whereby $30-79 \%$ of content is delivered online (Allen \& Seaman, 2005, p. 4).

To help identify the degree of blending which may occur within these two approaches, reference can be made to the 'Continuum Of Blended Learning', as shown in Figure 2, which provides a classification based on the level of online resources used. This begins at the most basic level of information and communication technology used to support face-to-face teaching through to intensive use, whereby the whole module is delivered online with minimal or no face-to-face interaction (Jones 2006).

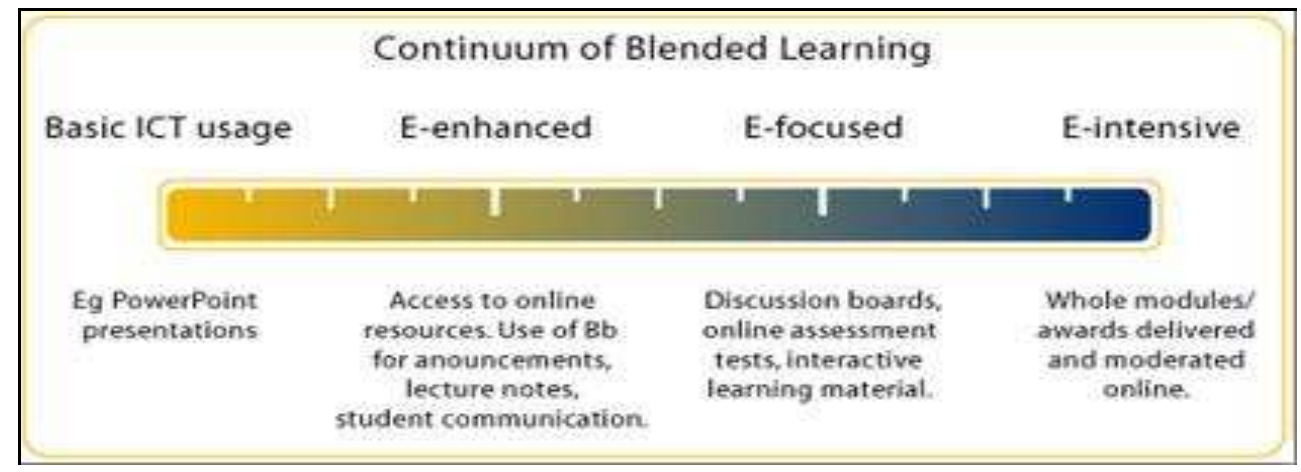

Figure 2 - Continuum of B lended Learning (Jones, 2008, p. 18)

Table 3 provides an overview of the nature and extent of online resources provided on the unit's WebCT site. With reference to Jones' Continuum of Blended Learning, this may be classified as an E-focused level of blended learning. 
Table 3: Profile of Online Resources Provided on WebCT Blackboard Learning Manage ment System for B AO1101

\begin{tabular}{|c|c|c|c|c|c|}
\hline & $\begin{array}{c}\text { Semester } \\
1 / 2006\end{array}$ & $\begin{array}{c}\text { Semester } \\
2 / 2006\end{array}$ & $\begin{array}{c}\text { Semester } \\
1 / 2007\end{array}$ & $\begin{array}{c}\text { Semester } \\
2 / 2007\end{array}$ & $\begin{array}{c}\text { Semester } \\
1 / 2008\end{array}$ \\
\hline \multicolumn{6}{|l|}{ Interacti ve Resources } \\
\hline online tests and solutions & $\mathrm{x}$ & $\mathrm{X}$ & $\mathrm{x}$ & $\mathrm{X}$ & $\mathrm{x}$ \\
\hline budgeting module & $\mathrm{x}$ & $\mathrm{x}$ & $\mathrm{x}$ & $\mathrm{x}$ & $\mathrm{x}$ \\
\hline franchising module & $\mathrm{x}$ & $\mathrm{x}$ & $\mathrm{x}$ & $\mathrm{x}$ & $\mathrm{x}$ \\
\hline email & $\mathrm{x}$ & $\mathrm{x}$ & $\mathrm{x}$ & $\mathrm{x}$ & $\mathrm{x}$ \\
\hline discus sion boards & & & & & $\mathrm{x}$ \\
\hline \multicolumn{6}{|l|}{ Informational Resources } \\
\hline updates on home page & $\mathrm{x}$ & $\mathrm{x}$ & $\mathrm{x}$ & $\mathrm{x}$ & $\mathrm{x}$ \\
\hline unit of study guide & $\mathrm{x}$ & $\mathrm{x}$ & $\mathrm{x}$ & $\mathrm{X}$ & $\mathrm{x}$ \\
\hline staff contact details & $\mathrm{x}$ & $\mathrm{x}$ & $\mathrm{x}$ & $\mathrm{X}$ & $\mathrm{x}$ \\
\hline lecture notes & $\mathrm{x}$ & $\mathrm{x}$ & $\mathrm{x}$ & $\mathrm{x}$ & $\mathrm{x}$ \\
\hline PowerPoint presentations & $\mathrm{x}$ & $\mathrm{x}$ & $\mathrm{x}$ & $\mathrm{x}$ & $\mathrm{x}$ \\
\hline tutorial material & $\mathrm{x}$ & $\mathrm{x}$ & $\mathrm{x}$ & $\mathrm{x}$ & $\mathrm{x}$ \\
\hline asses sment details & $\mathrm{x}$ & $\mathrm{X}$ & $\mathrm{x}$ & $\mathrm{x}$ & $\mathrm{x}$ \\
\hline assignment marking scheme & $\mathrm{x}$ & $\mathrm{x}$ & $\mathrm{x}$ & $\mathrm{x}$ & $\mathrm{x}$ \\
\hline sample mid-semester test and solutions & $\mathrm{x}$ & $\mathrm{x}$ & $\mathrm{x}$ & $\mathrm{x}$ & $\mathrm{x}$ \\
\hline past exam papers and solutions & $\mathrm{x}$ & $\mathrm{x}$ & $\mathrm{x}$ & $\mathrm{x}$ & $\mathrm{x}$ \\
\hline supplementary resources & $\mathrm{x}$ & $\mathrm{x}$ & $\mathrm{x}$ & $\mathrm{x}$ & $\mathrm{x}$ \\
\hline links to relevant websites & $\mathrm{x}$ & $\mathrm{x}$ & $\mathrm{x}$ & $\mathrm{x}$ & $\mathrm{x}$ \\
\hline text book online support & $\mathrm{x}$ & $\mathrm{x}$ & $\mathrm{x}$ & $\mathrm{x}$ & $\mathrm{x}$ \\
\hline video on differing roles in accounting & $\mathrm{x}$ & $\mathrm{x}$ & $\mathrm{x}$ & $\mathrm{x}$ & $\mathrm{x}$ \\
\hline video on peer mentoring program & & & & $\mathrm{x}$ & $\mathrm{x}$ \\
\hline video on study skills and plagiaris $m$ & & & & $\mathrm{X}$ & $\mathrm{x}$ \\
\hline updates via announcements & & & & & $\mathrm{x}$ \\
\hline
\end{tabular}

The interactive resources; online quizzes, budgeting module and franchise module gave students the opportunity to actively engage with custom-designed teaching materials to reinforce key concepts. With the WebCT email and discussion tools, online communication and access to all instructors and students within the unit was readily available. The use of the discussion board was introduced in Semester 1/2008 to encourage a greater level of communication than that received via email in previous semesters.

The informational resources comprise of important details relevant to the unit, lectures, tutorial and assessment. These materials are updated and improved each semester so that students are fully informed from the outset of the content to be covered and all the supporting resources are provided to help students keep on track with their learning activities throughout the semester. New resources are added as they become available. In Semester 2/2007, two in-house videos with unit specific content were included; one informed students of a peer mentoring program to support students with difficulties with the unit and the other featured study skills and issues about plagiarism. To enable direct access to important updates, the announcements feature was used more frequently in Semester 1/2008 to convey information relating to assessment and other relevant details. 


\section{Results}

\section{Learning Outcomes}

Rebele (2002) stresses the importance of further research on how technology can be effectively used in accounting education, and in particular, the need to test whether technology improves learning and how learning is improved. de Lange, Suwardy and Mavondo (2003) propose that the use of technology in the delivery of an introductory accounting unit may potentially increase the level of student motivation and satisfaction with the unit.

To determine whether the use of WebCT has had a positive impact on learning outcomes, comparisons were made to key performance measures including student evaluation of the first-year accounting unit, student performance on the mid-semester and the overall pass rate for the unit. The aggregate results of the university's local campuses were used to benchmark against 'prior to WebCT' results, over five consecutive semesters.

Table 4: Stude nt Evaluation of Unit

\begin{tabular}{|l|c|c|c|c|c|c|c|}
\cline { 2 - 8 } \multicolumn{1}{c|}{} & \multicolumn{2}{c|}{ Prior to WebCT } & \multicolumn{5}{c|}{ With WebCT } \\
\cline { 2 - 8 } \multicolumn{1}{c|}{} & $\begin{array}{c}\text { Semester } \\
\mathbf{1 / 2 0 0 5}\end{array}$ & $\begin{array}{c}\text { Semester } \\
\mathbf{2 / 2 0 0 5}\end{array}$ & $\begin{array}{c}\text { Semester } \\
\mathbf{1 / 2 0 0 6}\end{array}$ & $\begin{array}{c}\text { Semester } \\
\mathbf{2 / 2 0 0 6}\end{array}$ & $\begin{array}{c}\text { Semester } \\
\mathbf{1 / 2 0 0 7}\end{array}$ & $\begin{array}{c}\text { Semester } \\
\mathbf{2} / \mathbf{2 0 0 7}\end{array}$ & $\begin{array}{c}\text { Semester } \\
\mathbf{1 / 2 0 0 8}\end{array}$ \\
\hline Sample Size & 247 & 71 & 325 & 102 & 174 & 111 & 237 \\
\hline $\begin{array}{l}\text { A ver age Rating } \\
\text { out of 5 }\end{array}$ & $\mathbf{3 . 7 2}$ & $\mathbf{4 . 0 7}$ & $\mathbf{4 . 0 9}$ & $\mathbf{4 . 1 1}$ & $\mathbf{4 . 1 0}$ & $\mathbf{4 . 0 4}$ & $\mathbf{3 . 8 0 *}$ \\
\hline
\end{tabular}

* change in format to questionnaire, equivalent question related

the management of learning activities was used

To monitor the overall quality of the teaching and learning experience, a formal student evaluation of the unit is conducted at the end of each semester. The last question on the survey asks students to rate the quality of the unit. Students were also asked an open-ended question seeking their opinion of WebCT and whether it was considered a useful teaching resource. The average ratings show a gradual improvement in the students' perception of the unit and acknowledgement of the technical innovations to enhance the quality and flexibility in the delivery of teaching materials over this introductory period. (See Table 4.) The unit's rating peaked in Semester 2/2006 with 4.11 compared to a pre-WebCT rating of 3.72. The declining trend commenced in Semester $1 / 2007$ and reached its lowest point in Semester 1/2008 with an overall rating of 3.80, only slightly higher than 3.72 pre-WebCT score. This may be due to fact that WebCT is no longer a novelty factor as it was in 2006. From the demographic profile shown in Table 1, the most prominent group, those students between 20-29 years of age, is perhaps more demanding of the quality and range of online materials available as new technologies emerge. These issues have been raised in earlier studies on student motivation and its effect on levels of satisfaction (de Lange et al., 2003).

Table 5: Student Performance on Mid-Se mester Test

\begin{tabular}{|l|c|c|c|c|c|c|c|}
\cline { 2 - 8 } \multicolumn{1}{c|}{} & \multicolumn{2}{c|}{ Prior to WebCT } & \multicolumn{4}{c|}{ With WebCT } \\
\cline { 2 - 8 } \multicolumn{1}{c|}{} & $\begin{array}{c}\text { Semester } \\
\mathbf{1 / 2 0 0 5}\end{array}$ & $\begin{array}{c}\text { Semester } \\
\mathbf{2 / 2 0 0 5}\end{array}$ & $\begin{array}{c}\text { Semester } \\
\mathbf{1 / 2 0 0 6}\end{array}$ & $\begin{array}{c}\text { Semester } \\
\mathbf{2 / 2 0 0 6}\end{array}$ & $\begin{array}{c}\text { Semester } \\
\mathbf{1 / 2 0 0 7}\end{array}$ & $\begin{array}{c}\text { Semester } \\
\mathbf{2} / \mathbf{2 0 0 7}\end{array}$ & $\begin{array}{c}\text { Semester } \\
\mathbf{1 / 2 0 0 8}\end{array}$ \\
\hline Aggregate Score & $4,627.4$ & $1,637.0$ & $4,625.3$ & $2,178.2$ & $5,203.7$ & $2,052.9$ & $3,317.1$ \\
\hline Sample Size* & 743 & 278 & 779 & 373 & 903 & 404 & 619 \\
\hline $\begin{array}{l}\text { Average Mark } \\
\text { out of 10 }\end{array}$ & $\mathbf{6 . 2 2}$ & $\mathbf{5 . 8 8}$ & $\mathbf{5 . 9 3}$ & $\mathbf{5 . 8 3}$ & $\mathbf{5 . 7 6}$ & $\mathbf{5 . 0 8}$ & $\mathbf{5 . 3 6}$ \\
\hline
\end{tabular}

* Sample Size is based on number of students completing mid-semester test 
A mid-semester test conducted in Week 8, is a paper based multiple-choice test which contains both practical and theory content drawn from lectures and tutorials. (See Table 5.) It is a compulsory assessment conducted in class and accounts for $10 \%$ of the final grade.

By providing regular assessment with immediate feedback, the weekly online tests were considered beneficial in helping students prepare for their mid-semester test. However, the average mark attained by students for Semester 1/2006 and Semester 2/2006 of 5.93 and 5.83 respectively, were noticeably lower than those marks attained in Semester 1/2005 and Semester 2/2005, prior to the introduction of WebCT. This may be attributed to the lower ENTER scores for this period as shown in Table 2. The downward trend continued in Semester 1/2007 and reached its lowest point in the following period with an average test score of 5.08. It is of interest to note that in response to student feedback, in Semester 2/2007 students were allowed 2 attempts at the weekly online tests to help prepare for the mid-semester test, but the outcome was disappointing overall. Although there appears to be a considerable recovery in the following semester with the average test score increasing to 5.36, it is relatively lower than the scores recorded in the first semester for each of the previous years. Those students pursuing accounting and finance related majors are usually enrolled in the first semester to ensure proper sequencing of requisite accounting units. Consequently, mid-semester test results and overall pass rates tend to be higher in this period.

The implementation of WebCT online weekly tests did not seem to have a direct influence in improving students' performance on their mid-semester test. Its effectiveness may have been compromised by the low participation rates presented in Figure 3 and Table 6.

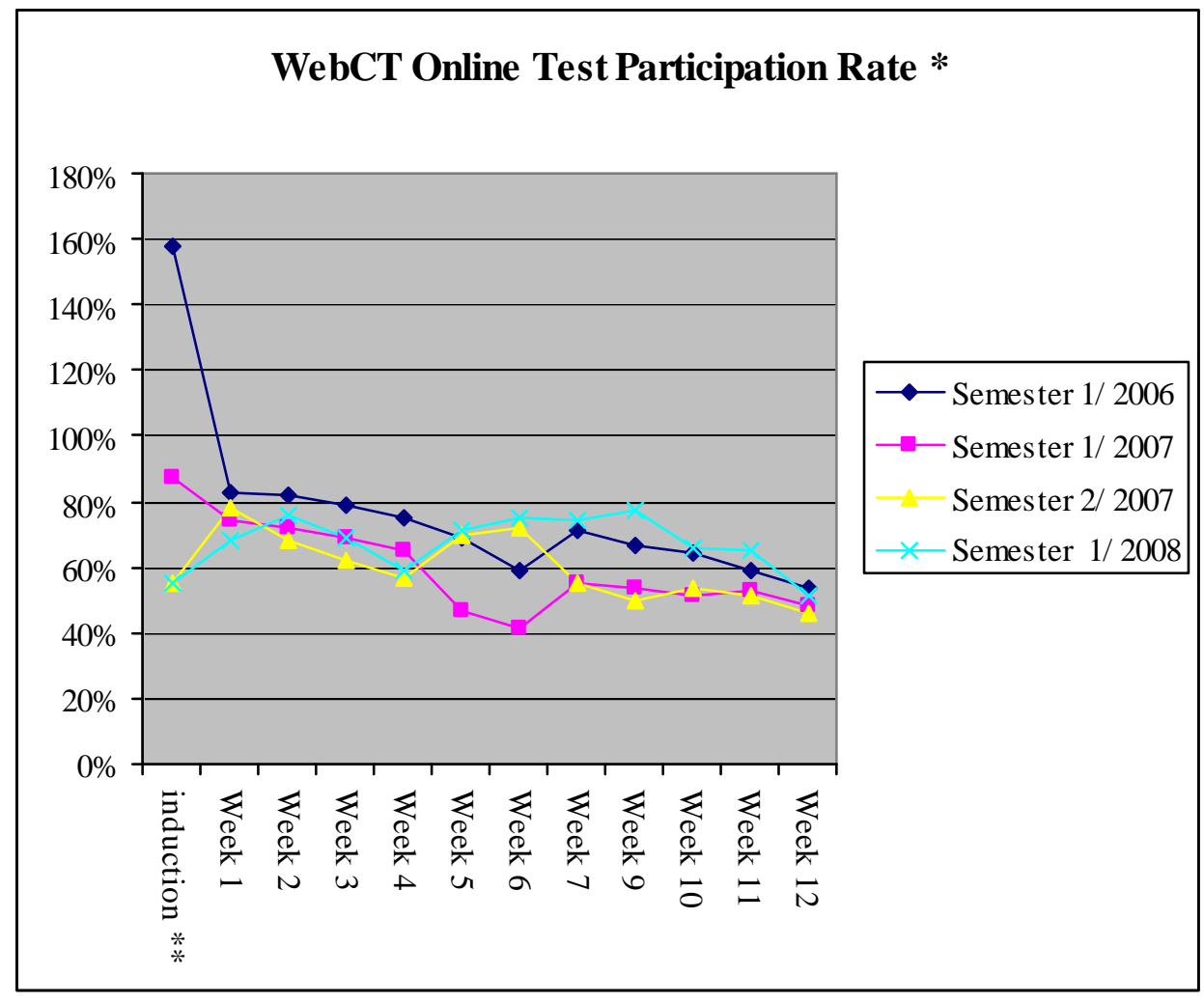

Figure 3. Test Participation Rates 
Table 6: Average Participation Rate

\begin{tabular}{|l|c|c|c|c|c|}
\hline & $\begin{array}{c}\text { Semester } \\
1 / 2006\end{array}$ & $\begin{array}{c}\text { Semester } \\
2 / 2006\end{array}$ & $\begin{array}{c}\text { Semester } \\
1 / 2007\end{array}$ & $\begin{array}{c}\text { Semester } \\
2 / 2007\end{array}$ & $\begin{array}{c}\text { Semester } \\
1 / 2008\end{array}$ \\
\hline $\begin{array}{l}\text { Number of Students Enrolled in } \\
\text { WebCT* }\end{array}$ & 1,150 & $* * *$ & 1,289 & 643 & $\mathbf{8 6 0}$ \\
\hline Aver age Participation Rate **** & $76.7 \%$ & $\mathbf{n} / \mathbf{a}$ & $\mathbf{5 9 . 7 \%}$ & $\mathbf{5 9 . 9 \%}$ & $\mathbf{6 7 . 3 \%}$ \\
\hline
\end{tabular}

Explanatory Notes for Figure 3 and Table 6

* Details accessed from WebCT Course Management Statistical Tools

** Induction Test encouraged multiple attempts

*** Semester 2/2006 results unavailable - WebCT database not retrievable for this period

**** Average Participation Rate was calculated by adding weekly participation rates and dividing by 12 weeks

In a recent study, Marriott and Lau (2008) explain the merits of phased online assessment, whereby a series of assessments are delivered throughout the course. This enables students to monitor their performance, and the timely feedback provided would be beneficial in improving their future performance. A similar approach was adopted in this unit, with the introduction of online tests to help students review and test their understanding of the content in the lectures and tutorials at regular intervals during the semester. These tests were released on a weekly basis and students were given two weeks to complete the test before it was closed and no longer available. It was necessary to impose a closing time so that the results could be used to identify 'at-risk' students in a timely manner. This 'assessment audit' (Marriott \& Lau 2008), would then provide indication of the necessary action to be taken to support this particular group of students. Further discussion on 'at-risk' students is provided under Table 8 - Retention Rates, although it is acknowledged that this cannot provide causal information.

For each test, a time limit of 30 minutes was allowed for students to complete a short multiplechoice test comprising 15 questions. This was a combination of theoretical and practical questions which were randomly generated for each student. It was also considered important to place a time limit for the duration of the online test as it would raise student awareness of time constraints and managing time effectively. Being disciplined in this respect would enable students to be better prepared for the mid-semester test and final examination, as students are required to complete these assessments within a confined time limit.

In Semester 1/2006 when the tests were first introduced, students were allowed one attempt only and students were instructed to practice using the Induction Test. Multiple attempts were encouraged to become familiar with its style and format before attempting the weekly tests, which accounted for $10 \%$ of the total assessment. Figure 3 shows an initial response rate of $158 \%$ for the Induction Test, the results reflected a high level of enthusiasm for this new form of assessment at the beginning semester, which seems consistent with findings in earlier studies which noted an improvement in student learning when the method of assessment changed (Greer, 2001). However, as the semester progressed, the participation rate for the weekly tests showed a constant decline throughout, with a low of $54 \%$ by the end of the semester. With reference to Table 6 , the average participation rate for first semester was 77\%. This downward trend continued in the following semesters, by Semester 1/2007 this had deteriorated to 60\%. In response to student feedback and an attempt to improve the level of participation for Semester 2/2007, students were allowed two attempts at the test, with the higher score counting toward their final assessment. As only a marginal increase resulted from this, it was decided in Semester 1/2008 to revert back to the original situation of one attempt only. The average participation rate $67 \%$ for this period showed a signif icant improvement, with an increasing level of participation leading up to the 
Week 8 test. Along with the use of online announcements and discussion tools, these factors may have attributed to the higher test results.

Table 7: Ove rall Pass Rate

\begin{tabular}{|l|c|c|c|c|c|c|c|}
\cline { 2 - 8 } \multicolumn{1}{c|}{} & \multicolumn{2}{c|}{ Prior to WebCT } & \multicolumn{5}{c|}{ With WebCT } \\
\cline { 2 - 8 } \multicolumn{1}{c|}{} & $\begin{array}{c}\text { Semester 1/ } \\
\mathbf{2 0 0 5}\end{array}$ & $\begin{array}{c}\text { Semester 2/ } \\
\mathbf{2 0 0 5}\end{array}$ & $\begin{array}{c}\text { Semester 1/ } \\
\mathbf{2 0 0 6}\end{array}$ & $\begin{array}{c}\text { Semester 2/ } \\
\mathbf{2 0 0 6}\end{array}$ & $\begin{array}{c}\text { Semester 1/ } \\
\mathbf{2 0 0 7}\end{array}$ & $\begin{array}{c}\text { Semester 2/ } \\
\mathbf{2 0 0 7}\end{array}$ & $\begin{array}{c}\text { Semester 1/ } \\
\mathbf{2 0 0 8}\end{array}$ \\
\hline $\begin{array}{l}\text { Sample } \\
\text { Size } *\end{array}$ & 726 & 266 & 729 & 361 & 927 & 430 & 591 \\
\hline Pass & 42 & 187 & 486 & 251 & 719 & 325 & 455 \\
\hline $\begin{array}{l}\text { Pass } \\
\text { Rate }\end{array}$ & $\mathbf{7 4 . 6 \%}$ & $\mathbf{7 0 . 3 \%}$ & $\mathbf{6 6 . 7 \%}$ & $\mathbf{6 9 . 5 \%}$ & $\mathbf{7 7 . 6 \%}$ & $\mathbf{7 5 . 6 \%}$ & $\mathbf{7 6 . 9 \%}$ \\
\hline
\end{tabular}

* Sample Size is based on number of students completing final exam

As shown in Table 7, the overall pass rate for the unit in Semester 1/2006 and Semester 2/2006 of $66.7 \%$ and $69.5 \%$ respectively, is significantly lower than the overall pass rate attained in the semesters prior to the introduction of WebCT. This may also be reflective of the lower ENTER scores for this period. There is, however, an improvement from Semester 1/2006 to Semester $2 / 2006$ with a slight increase in the overall pass rate from $66.7 \%$ to $69.5 \%$. This may have been attributed to the initial teething problems in the very first semester experienced by both staff and students becoming accustomed to WebCT. As students had acquired a greater familiarity with WebCT by Semester 2/2006 through its adoption by other units being studied, the weekly online testing and immediate feedback appeared to help improve student performance in their final exam. The most significant improvement in the pass rate was from Semester 1/2007 onwards, increasing from $69.5 \%$ to around $78 \%$, and then remaining consistent over the next two semesters. This trend appears consistent with the students' performance on their mid-semester test shown in Table 5. The gradual increase in the WebCT Online Test Participation Rate over this period may have also impacted on the academic performance in this unit.

Table 8: Retention Rate

\begin{tabular}{|l|c|c|c|c|c|c|c|}
\cline { 2 - 8 } \multicolumn{1}{c|}{} & \multicolumn{2}{c|}{ Prior to WebCT } & \multicolumn{5}{c|}{ With WebCT } \\
\cline { 2 - 8 } & $\begin{array}{c}\text { Semester } \\
\mathbf{1 / 2 0 0 5}\end{array}$ & $\begin{array}{c}\text { Semester } \\
\mathbf{2 / 2 0 0 5}\end{array}$ & $\begin{array}{c}\text { Semester } \\
\mathbf{1 / 2 0 0 6}\end{array}$ & $\begin{array}{c}\text { Semester } \\
\mathbf{2 / 2 0 0 6}\end{array}$ & $\begin{array}{c}\text { Semester } \\
\mathbf{1 / 2 0 0 7}\end{array}$ & $\begin{array}{c}\text { Semester } \\
\mathbf{2 / 2 0 0 7}\end{array}$ & $\begin{array}{c}\text { Semester } \\
\mathbf{1 / 2 0 0 8}\end{array}$ \\
\hline $\begin{array}{l}\text { Number of Students } \\
\text { Enro lled* }\end{array}$ & 930 & 421 & 1,002 & 533 & 1,050 & 457 & 719 \\
\hline $\begin{array}{l}\text { Number of Students } \\
\text { Completed Final } \\
\text { Exam }\end{array}$ & 726 & 266 & 729 & 361 & 927 & 430 & 591 \\
\hline \begin{tabular}{l} 
Retention Rate \\
\hline
\end{tabular} & $\mathbf{7 8 \%}$ & $\mathbf{6 3 \%}$ & $\mathbf{7 3 \%}$ & $\mathbf{6 8 \%}$ & $\mathbf{8 8 \%}$ & $\mathbf{9 4 \%}$ & $\mathbf{8 2 \%}$ \\
\hline
\end{tabular}

* from VUSIS enrolment data 2005 to 2008

With the Blackboard Learning System's tracking feature, it is possible to collect statistical data to monitor student progress throughout the semester. Ross and Gage (2006) suggest that this ins ight into student activity and learning behaviour will help identify those students not keeping up with their learning activities. Early intervention by the instructor may prevent these 'at-risk' students from failing or dropping out and therefore improve the retention rate.

In this unit, performance on the weekly online tests was used to determine whether the student was 'at risk'. (See Table 8.) Students who did not pass or attempt 3 out of 5 tests were placed in this category and sent individual letters from the Faculty of Business and Law. Students were informed of their 'at risk' status and advised to seek assistance with their studies. In this intro- 
ductory unit, there is a weekly student mentoring session which is specifically set up to support students with difficulties in this area.

Whilst the retention rates fluctuated during the first two semesters of 2006, a substantial improvement was evident in the following year, with the highest retention rate of $94 \%$ attained in Semester 2/2007. Although a marked drop back to $82 \%$ was recorded in Semester $1 / 2008$, this is still greater than the retention rates recorded prior to the introduction of WebCT. The general upward trend seems to suggest that the availability and usage of the tracking statistics to monitor student progress may have had an impact on improving the levels of student retention in this unit. This is an encouraging outcome given the trend toward increasing number of students accepted with a lower ENTER score as shown in Table 2.

\section{Conclusion}

Although the introduction of WebCT and greater availability of online teaching resources was reflected in the gradual improvement of student evaluation of the unit during the earlier phases, the latter periods show a marked drop in the level of student satisfaction. There were similar observations recorded for the level of student enthusiasm toward online assessment. As reported in Greer (2001) and Nicol (2006), changes to assessment and innovative use of computer based assessment may positively impact on learning. However, in this study it was found that whilst students responded well initially to this change in assessment, participation rates for the weekly online tests dropped significantly over subsequent semesters. The implementation of WebCT online weekly tests did not seem to have a direct influence in improving students' performance on their mid-semester test. Despite the increasing amount of resources available to assist students, the general decline in the ir score on the mid-semester test was a disappointing outcome As WebCT is no longer the novelty it was in 2006 , this change in attitude may be reflective of the younger students, in particular, becoming more demanding of the quality and range of online materials available as new technologies rapidly emerge. As identified in their research on student motivation, 'the challenge for educators is to develop strategies that ensure any novelty effect does not wear off with an end result of technology impeding learning' (de Lange et al 2003, p.11). A more favourable trend is noted with the most recent overall pass rates and retention rates for the unit. These results are consistent with recent findings (Ross and Gage 2006). With the availability of statistical tracking data from the course management system, both measures improved beyond those prior to the introduction of WebCT.

With the changing nature of accounting education, Rebele (2002) highlighted the importance of research specific to the effective use of technology in accounting education. In a review of more recent literature by Marriott and Lau (2008), the paucity of research in this area is still evident. With the increasing prominence of blended learning in higher education (Bonk \& Graham ,2006), the need for this research has become more prevalent. By addressing some of the key issues associated with the greater use of technology in the curriculum and evaluating its impact on learning outcomes, this preliminary study contributes to this current gap in research.

There may also be scope for future research in investigating the force of personality and presence in a teaching and learning environment. The level and quality of interaction between student and instructor may have a significant impact on student learning and satisfaction. 


\section{References}

Allen, I. E., \& Seaman, J. (2005). Growing by degrees - Online education in the United States. The Sloan Consortium. Retrieved October 21, 2008, fro m http://www.sloanc.org/publications/survey/pdf/growing by degrees.pdf

Bliuc, A., Goodyear, P., \& Ellis, R. A. (2007). Research focus and methodological choices in studies into students' experiences of blended learning in higher education. The Internet and Higher Education, 10(4), 231-244.

Bonk, C. J., \& Graham, C. R. (2006). The handbook of blended learning - Global perspectives, local designs. CA: Pfeiffer - An Imprint of Wiley.

de Lange, P., Suwardy, T.,. \& Mavondo, F. (2003). Integrating a virtual learning environ ment into an introductory accounting course: Determinants of student motivation. Accounting Education, 12(1), 1-14.

Garrison, D. R., \& Vaughan, N. D. (2008). Blended learning in higher education - Framework, principles and guidelines. CA: Jossey-Bass - A Wiley Imprint.

Greer, L. (2001). Does the method of as sessment of a module improve the performance of a student? Assessment and Evaluation in Higher Education, 26(2), 127-138.

Jones, N. (2006). E-College Wales: A case study of blended learning. In C. J. Bonk \& C. R. Graham (Eds.), The handbook of blended learning - Global perspectives, local designs (pp.182-193). CA: Pfeiffer - An Imprint of Wiley.

Jones, N. (2008). Over the worst or at the eye of the storm? Retrieved August 5, 2008, from http://hdl.handle.net/10265/249

Marriott, P., \& Lau, A. (2008). The use of on-line summative assessment in an undergraduate financial accounting course. Joumal of Accounting Education, 26(2), 73-90.

Mc Innis, C., James, R., \& Mc Naught, C. (1995). First year on campus - Diversity in the initial experience of Australian undergraduates. Australia, University of Melbourne, Centre for the Study of Higher Education.

Mintz, S., \& Cherry, A. A. (1993). The introductory accounting courses: Educating majors and nonmajors. Journal of Education for Business, 68(5), 276-280.

Mladenovic, R. (2000). An investigation into ways of challenging introductory accounting student's negative perceptions of accounting. Accounting Education, 9(2), 135-155.

Nicol, D. (2006, December). Increasing success in first year courses: Assessment re-design, self-regulation and learning technologies. Proceedings of the 23rd Annual ASCILITE Conference: Who's learning? Whose technology?, Sydney, Australia, 589-598.

Rebele, J. E. (2002). Accounting education's uncertain environments: Descriptions and implications for accounting programmes and accounting education research. Accounting Education, 11(1), 3-25.

Ross, B., \& Gage, K. (2006). Global perspectives on blended learning, In C. J. Bonk \& C. R. Graham (Eds.), The handbook of blended learning - Global perspectives, local designs (pp.155-167). CA: Pfeiffer - An Imprint of W iley.

Wells, P., de Lange, P., \& Fieger, P. (2008). Integrating a virtual learning environ ment into a second-year accounting course: Determinants of overall student perception. Accounting \& Finance, 48(3), 503-518. 


\section{Biographies}

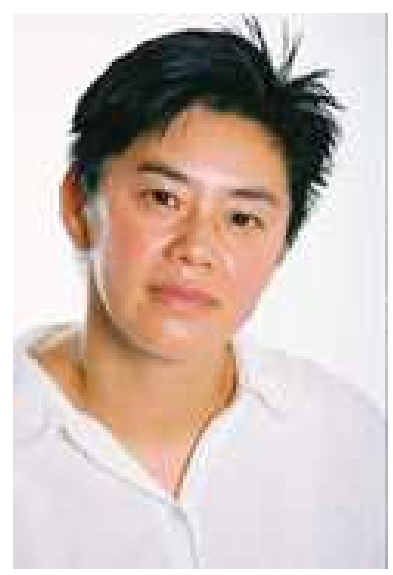

Lily Wong is the Unit Coordinator for Introductory Accounting, one of the largest student cohorts at Victoria University. Since undertaking this position in 2003, she has been actively involved in the research, development and integration of online teaching resources to improve the student learning experience. Lily's contribution to teaching and learning has been formally recognised as a recipient of Victoria University's Vice-Chancellor's Award for Teaching Excellence and as a finalist in the Australian Awards for University Teaching.

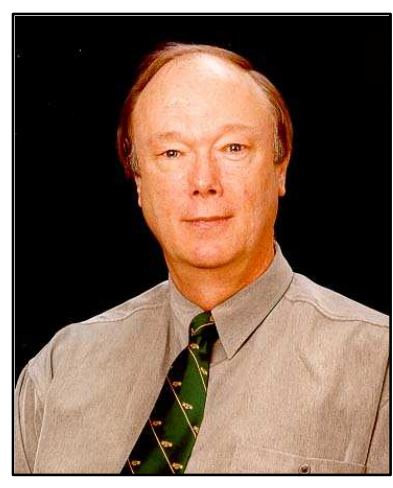

Arthur Tatnall is an Associate Professor in the Graduate School of Business at Victoria University in Melbourne, Australia. He holds bachelors degrees in Science and Education, a Graduate Diploma in Computer Science, and a research Master of Arts in which he explored the origins of Information Systems curriculum in Australian universities. His $\mathrm{PhD}$ involved a socio-technical study in curriculum innovation in which he investigated the manner in which Visual Basic entered the curriculum of an Australian university. His research interests include technological innovation, history of technology, information systems curriculum, project management, electronic commerce, and information technology in educational management. 